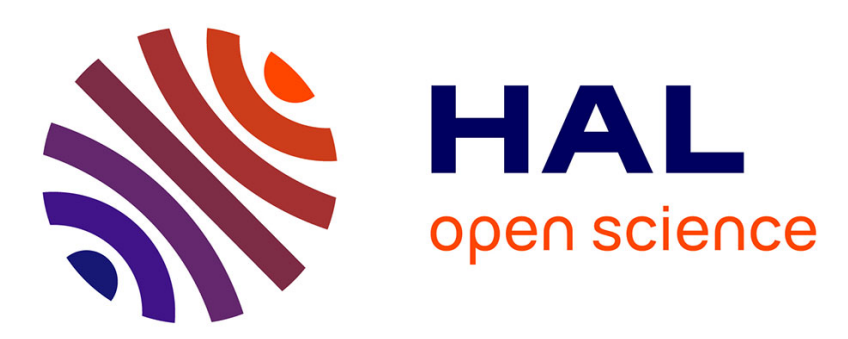

\title{
Integration and religiosity among the Turkish second generation in Europe: A comparative analysis across four capital cities
}

\author{
Fenella Fleischmann, Karen Phalet
}

\section{- To cite this version:}

Fenella Fleischmann, Karen Phalet. Integration and religiosity among the Turkish second generation in Europe: A comparative analysis across four capital cities. Ethnic and Racial Studies, 2011, PP (PP), pp.1. 10.1080/01419870.2011.579138 . hal-00716628

\section{HAL Id: hal-00716628 \\ https://hal.science/hal-00716628}

Submitted on 11 Jul 2012

HAL is a multi-disciplinary open access archive for the deposit and dissemination of scientific research documents, whether they are published or not. The documents may come from teaching and research institutions in France or abroad, or from public or private research centers.
L'archive ouverte pluridisciplinaire HAL, est destinée au dépôt et à la diffusion de documents scientifiques de niveau recherche, publiés ou non, émanant des établissements d'enseignement et de recherche français ou étrangers, des laboratoires publics ou privés. 


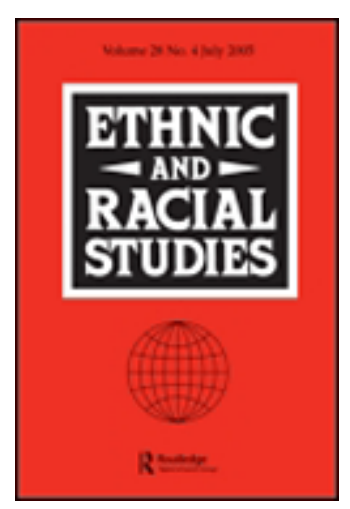

Integration and religiosity among the Turkish second generation in Europe:

A comparative analysis across four capital cities

\begin{tabular}{|r|l|}
\hline Journal: & Ethnic and Racial Studies \\
\hline Manuscript ID: & RERS-2011-0021.R1 \\
\hline Manuscript Type: & Original Manuscript \\
\hline Keywords: & $\begin{array}{l}\text { Integration, Religion, Islam, Second Generation, Institutions, } \\
\text { comparative approach }\end{array}$ \\
\hline \multicolumn{2}{|l}{} \\
\hline
\end{tabular}

\section{SCHOLARONE" \\ Manuscripts}




\title{
Integration and religiosity among the Turkish second generation in Europe:
}

\section{A comparative analysis across four capital cities}

\begin{abstract}
Drawing on recent cross-national surveys of the Turkish second generation, we test hypotheses of secularization and of religious vitality for Muslim minorities in Europe. Secularization predicts an inverse relationship between structural integration and religiosity, such that the Turkish second generation would be less religious with higher levels of educational attainment and intermarriage. The religious vitality hypothesis predicts the maintenance of religion in the second generation, highlighting the role of religious socialization within immigrant families and communities. Taking a comparative approach, these hypotheses are tested in the context of different national approaches to the institutionalization of Islam as a minority religion in four European capital cities: Amsterdam, Berlin, Brussels and Stockholm. Across contexts, religious socialization strongly predicts second-generation religiosity, in line with religious vitality. The secularization hypothesis finds support only among the second generation in Berlin, however, where Islam is least accommodated.
\end{abstract}

Key words: integration; religion; Islam; second generation; institutions; comparative approach 
Integration and religiosity among the Turkish $2^{\text {nd }}$ generation

\section{Introduction}

Large-scale immigration of Muslims to North-Western Europe's highly secularized societies has raised the question of how the local-born children of Muslim immigrants relate to, and practice their religion. Being socialized with Islam within their families and local co-ethnic communities (Güngör et al., forthcoming), the second generation grows up in societies where the majority is historically Christian, highly secularized and increasingly anti-Islamic. This study examines religiosity among the Turkish second generation and asks how it relates to their religious socialization in immigrant families and communities and to their structural integration into European societies. Moreover, we investigate contextual variation in the relationship between structural integration and religiosity across four European capital cities Amsterdam, Berlin, Brussels and Stockholm - which represent different national traditions of church-state relations and distinct patterns of institutional incorporation of Islam.

Due to limited data availability, we currently lack comparative empirical evidence on second-generation Muslims' religiosity in Europe. Previous studies were often restricted to the foreign-born first generation; they used narrow measures of religious affiliation and worship; and/or they were single-country studies (Diehl and Koenig, 2009, Phalet et al., 2008, Van Tubergen, 2007). Comparative studies of religiosity among Muslim minorities in Europe remain an exception (but see Connor, 2010). Recent cross-national surveys from the TIESproject (The Integration of the European Second generation, see e.g. Crul and Schneider, 2010) allow comparative investigations of multiple dimensions of religiosity among the Turkish second generation. Due to their different national histories of church-state relations, the four countries in our study - Belgium, Germany, the Netherlands and Sweden - are characterized by different opportunity structures for the practice of Islam by Muslim minorities (Bader, 2007, Fetzer and Soper, 2005). Against this comparative background, we assess theoretical expectations of religious decline and vitality in the second generation.

In the following, we first present our theoretical framework and derive hypotheses about individual-level determinants of religious decline and religious vitality in the second generation. Next, we derive hypotheses about contextual differences in the relation between 
second-generation integration and religiosity from an institutionalist approach to the incorporation of Islam in European societies. Before putting our hypotheses to a test, we briefly describe the groups and contexts under study and the data and methods applied.

\section{The hypothesis of religious decline: structural integration and secularization}

The secularization paradigm posits the erosion of religion through modernization processes, as evident from the progressive separation of church and state and from declining religious attendance (Dobbelaere, 1981). Religious decline has been firmly established among European majority populations (Gorski and Altinordu, 2008) and secularization has become an ideology - in stark contrast with the US. As Casanova (2003, p.19) puts it: 'Americans think that they are supposed to be religious, while Europeans think that they are supposed to be irreligious'. Contrary to the US, in European societies religion is commonly portrayed as hindering immigrant integration (Foner and Alba, 2008).

Consequently, the classic assimilation hypothesis, which predicts that immigrants' life chances and life styles will gradually converge with those of natives over time and generations (Gordon, 1978 [1964]), when applied to the religious domain, amounts to a secularization hypothesis in European societies. Accordingly, our first hypothesis expects that second-generation Muslims will be less religious the more they are integrated into the mainstream (Hypothesis 1) in terms of social mixing and socio-economic inclusion relative to a non-immigrant reference population (Esser, 2001). Specifically, we predict that higher education and labour market participation as well as intermarriage with a non-Turkish partner will go together with lower levels of religiosity. Similar predictions can also be derived from the sociology of religion. Here, the expected inverse relationship of religiosity with education and labour market attainment is explained through increased exposure to a secular worldview (Berger, 1967) or through decreased economic uncertainty (Norris and Inglehart, 2004).

Research among Turkish and Moroccan minorities in the Netherlands (Van Tubergen, 2007, Phalet et al., 2008) and in Belgium (Lesthaeghe and Neels, 2000, Smits et al., 2010) largely confirms secularization in the sense of an inverse relationship between socio- 
Integration and religiosity among the Turkish $2^{\text {nd }}$ generation

economic attainment and religiosity. A more recent analysis, however, indicates an emerging trend towards religious revival particularly among more highly educated second-generation Dutch Muslims (Maliepaard et al., 2010). Similarly in Germany, Diehl and Koenig (2009) found remarkable stability instead of religious decline between migration generations. To our knowledge, there is no comparable evidence from large-scale surveys on religion and integration in Sweden.

\section{The hypothesis of religious vitality: religious socialization and reactive religiosity}

An alternative hypothesis expects religious vitality, defined as the continuity of a minority religion through the religious socialization of the next generation within the family and the co-ethnic community, in parallel with a notion of ethno-linguistic vitality in socio-linguistic studies of minority languages (Harwood et al., 1994). Turkish immigrants come from a majority Muslim society where levels of religiosity are much higher than in Germany, Belgium, the Netherlands or Sweden (Norris and Inglehart, 2004). This raises the question to what extent Turkish immigrants pass on Islamic traditions and practices to the next generation who are growing up in historically Christian and highly secularized European societies. Religious studies document the importance of a religious upbringing so that the children of more religious parents will themselves be more religious as adults (Kelley and De Graaf, 1997). Accordingly, we predict that the Turkish second generation will be more religious when their parents visited the mosque more often during their youth and/or when they attended Koran lessons as children (Hypothesis 2).

A complementary hypothesis of religious reactivity expects increased religiosity in the second generation in response to societal exclusion and experiences of discrimination. This hypothesis extends a notion of reactive ethnicity among most deprived secondgeneration groups in the US (Portes and Rumbaut, 2001) to the religious domain. The reactive religiosity hypothesis mirrors the inverse relation between socio-economic attainment and religiosity that is also predicted by the secularization hypothesis. In addition, however, 
reactivity implies a positive association between perceived discrimination and religiosity (Hypothesis 3).

\section{The institutionalization of Islam: contextual differences}

European nation-states differ substantially in their accommodation of Islam, because the institutionalization of this minority religion builds on pre-existing national patterns of churchstate relations (Bader, 2007, Koenig, 2007). Distinct institutional pathways thus provide different opportunity structures for the institutionalization of Islam (Statham et al., 2005).

Among our four comparison countries, the formal accommodation of Islam is most advanced in the Netherlands. Due to the history of 'pillarization' (Lijphart, 1968) and despite increasing secularization among the majority population, pluralist church-state relations created opportunities for Muslims to develop their own institutions (Rath et al., 1996). Thus, Dutch Muslims have established numerous local mosque associations, as well as state-funded Islamic broadcasting networks and Islamic schools (Doomernik, 1995). From an institutional perspective, Dutch Muslims were granted formal equality with Christian and other religious groups from the early 1980s onwards; and they made the most of the opportunities offered by the Dutch system.

In Germany, the institutional position of Islam is the most underprivileged by comparison. Due to their formal status as corporations of public law, Christian churches in Germany profit from taxes collected by the state. In the absence of a centralized organizational structure of German Muslims similar to that of the Christian churches, German authorities have refrained from granting Islam the same legal status (Fetzer and Soper, 2005). Consequently, Islamic organisations in Germany, lacking legal recognition and financial support, remain disadvantaged relative to established churches.

In Belgium, the status of Islam is formally equal to that of the historically dominant Catholic Church since 1974. Yet, in order to receive the state funding for religious services to which they are legally entitled, Muslim communities were required to set up a nationally representative Islamic council as a partner for the Belgian state (Foblets and Overbeeke, 
2002). Such a council has been established only recently upon the initiative of the Belgian authorities (Manço, 2000, Kanmaz, 2002). Because of the delayed implementation of the recognition of Islam, Islamic organizational structures are less fully developed in Belgium than they are in the Netherlands.

Finally, in Sweden Islam enjoys the same legal status as other religions and Islamic organisations, which are entitled to state funding proportionally to the size of their membership. However, Sweden has historically known a state church, which still counts more than 80 per cent of the Swedish population as its members (Alwall, 2000). Although the privileged position of the Swedish Lutheran Church has been dismantled in the second half of the twentieth century, the legacy of the state church system implies that Islam occupies a relatively marginal position. In spite of recent reforms, the Swedish religious landscape continues to be marked by a quasi-monopoly of the Swedish Lutheran Church.

From an institutionalist perspective, the position of Islam as a minority religion is most equal in the Netherlands and most unequal in Germany, with Belgium and Sweden granting some degree of recognition. Regarding our main research question about the relation between integration and religiosity, we reason that institutional opportunity structures can make the difference between complementary expectations of second-generation religious vitality or decline. Thus, we expect that upward integration will go together with decreased religiosity mainly in national contexts which do not recognize Islam nor facilitate its practice. When Islamic religion is excluded by mainstream institutions, the continued religiosity of Muslims stands in the way of successful integration. Conversely, in national contexts where the state recognizes and accommodates Islam, there will be more room for religiosity also among more integrated Muslims. We therefore predict an inverse relationship between integration and religiosity in contexts where the institutional accommodation of Islam is most restricted; and zero or even positive relationships where Islam has been more fully institutionalized (Hypothesis 4).

Institutionalist approaches in migration studies have been criticized for their formalistic and overly static conception of social processes, which would by-pass alternate 
resources and forms of agency 'from below' as well as ongoing socio-political struggles about institutional inequalities (Bousetta, 2000). Moreover, institutional arrangements may be far removed from public opinion in European societies. For instance, while the institutional accommodation of Islam is most advanced in the Netherlands, the position of Islam and Muslims is highly contested in Dutch media and politics and, despite constitutionally enshrined religious pluralism, Muslims are increasingly and overtly rejected by the Dutch majority population (Sniderman and Hagendoorn, 2007). Moreover, the capital cities each add their own local flavour to the distinct national approaches of church-state relations. Yet, they are strategic sites for comparative research as the localities where national and local policies intersect and where most minorities are concentrated. Due to the path-dependency of institutional arrangements, distinct national histories of church-state relations impose differential constraints on the development of religious organizations and institutions by immigrant communities. From a comparative perspective, therefore, we expect a long-term impact of institutional arrangements on patterns of integration and religiosity, over and above variation resulting from short-term changes in public opinion and policy. Moreover, we argue that our comparison of capital cities is well-suited to bring out such national differences.

\section{The Turkish second generation in North-Western Europe}

Turkish immigrants first arrived in the Netherlands, Germany and Belgium as so-called 'guest workers' and later through family-based migration. (Lesthaeghe, 2000, Vermeulen and Penninx, 2000, Münz et al., 1997). In the Swedish context labour migration has been less important as the country received relatively more refugees (Corman, 2008). Therefore, the Turkish-Swedish population is comparatively small and includes substantial shares of Kurdish and Assyrian refugees. Assyrians, who are mainly Orthodox Christians (Sander, 1990), are excluded from our analysis for reasons of comparability. Turks are the largest non-European minority group in the Netherlands; including naturalized Turks and the second generation, they numbered 0.38 million, which is 2.3 per cent of the total population in 2009 (Statline, 2010). Similarly, in Germany, Turkish immigrants and their offspring are the largest 
Integration and religiosity among the Turkish $2^{\text {nd }}$ generation

immigrant minority with an estimated 2.5 million members, which constitutes 3.1 per cent of the total German population in 2009 (Statistisches Bundesamt, 2010). In Belgium, Turks are the third largest ethnic minority group, which numbered approximately 150,000 or 1.5 per cent of the total Belgian population in the 2001 Census (Phalet et al., 2007). Finally, in Sweden, the size of the Turkish minority amounted to approximately 60,000 persons in 2000, or about 0.7 per cent of the Swedish population, including the Swedish-born second generation (Westin, 2003).

\section{Data and Method}

The TIES-surveys

Our analysis draws on new comparative survey data among the Turkish second generation in Amsterdam (NIDI-IMES, 2007, TIES06-07-Netherlands), Berlin (IMIS, 2008, TIES08Germany), Brussels (CESO-CSCP, 2008, TIES07-08-Belgium) and Stockholm (CEIFO, 2008, TIES08-Sweden). The Turkish second generation is narrowly defined as the local-born children of immigrants from Turkey. Only young adults between 18 and 35 years old were sampled. Different sampling frames and response rates challenge the representativeness and comparability of minority samples in comparative surveys. In Amsterdam and Stockholm, random samples of native-born children of Turkish-born parents could be drawn from population registers. In Brussels, screening had to be applied to addresses in street segments which were sampled proportionally to the numbers of Turkish inhabitants. In Berlin, a random sample was drawn from a list of names generated by onomastic analysis identifying persons of Turkish origin within the population of 18-35 year old German-born residents of Berlin. For further information regarding sampling and fieldwork, readers are referred to the technical reports (Renstrand and Lundström, 2008 for Sweden, Groenewold, 2008 for the Netherlands, Swyngedouw et al., 2008 for Belgium; no technical report is available so far for Germany). Reported response rates were 29 per cent in Stockholm, 30 per cent in Amsterdam, and 31 per cent in Brussels and Berlin. Low response rates are due in part to the quality of available address lists in cities and neighbourhoods with high mobility rates and in part to 
generally low cooperation rates in inner cities, in young age groups, and in ethnic minority populations (Stoop et al., 2010). These data constraints should be kept in mind when drawing conclusions from our comparative analyses.

To ensure that our comparative results are not driven by differential selectivity of Turkish immigrants across the cities, a detailed comparison was undertaken of the characteristics of the parents of TIES-participants, i.e., the Turkish first generation. ${ }^{1}$ The comparison revealed very few differences in parental characteristics between the four cities. Most parents matched the typical profile of Turkish guest worker migration to North-Western Europe. Because the parents of Turkish Muslims in Brussels and Stockholm had somewhat higher levels of education, we include parental education as a control variable. Furthermore, we conducted logistic regression analyses to examine differential selectivity of selfcategorized Muslims across cities (see Note 4).

\section{Measures}

Religious identification was measured by four items reflecting participants' attachment to a common Muslim identity, e.g., "Being a Muslim is an important part of my self" (see Table 1 for the other items). They rated their agreement on five-point Likert-scales ranging from one (totally disagree) to five (totally agree).

Four indicators of religious practices were used to form two composite indices, labelled dietary practices and worship. Dietary practices refer to fasting during the last Ramadan and eating halal food; worship refers to saying daily prayers and attending religious services (i.e., visiting a mosque). ${ }^{2}$ While interrelated, it is useful to distinguish between worship and dietary practices as they form distinct clusters in K-means cluster analyses across the same Turkish Muslim populations (Phalet et al., in preparation).

An additional political dimension of religiosity, labelled political religion, is assessed by four statements expressing support for the role of Islam in politics and its representation in the public sphere, e.g., "Islam should be represented in politics and society" (see Table 1 for the remaining items). 
Integration and religiosity among the Turkish $2^{\text {nd }}$ generation

\section{Explanatory variables}

To assess the structural integration of the Turkish second generation, measures of educational attainment and employment status were used, along with marital status and ethnicity of the partner as a measure of social mixing in primary ties.

Four categories of educational attainment were distinguished based on participants' highest level of education completed or currently attended: lower secondary or less, vocational and academic upper secondary, and tertiary qualifications. ${ }^{3}$

Regarding employment status, we distinguish between working (employed or selfemployed), unemployed, full-time student, or otherwise inactive participants.

Furthermore, we looked at the ethnicity of the partner, with a non-Turkish partner as a proxy for intermarriage outside the ethnic community of co-religionists. We distinguish between participants who had no partner, those who had a partner of Turkish origin, or a nonTurkish partner. Partners were categorized as Turkish when they, or one of their parents, were born in Turkey, thus including the second generation.

Two indicators were used to assess religious childhood socialization. A dummy variable indicates whether participants have attended Koran lessons outside school hours as a child. In addition, participants reported the frequency of parents' mosque visits during their youth on a five-point scale ranging from one (never) to five (once a week or more).

To test the reactive religiosity hypothesis, we used two questions on perceived discrimination. Participants were asked to rate the frequency with which they had personally experienced unfair treatment or hostility due to their background (perceived personal discrimination); and how often they thought that Muslims as a group experienced unfair treatment or hostility (perceived group discrimination). Although personal and group level perceptions of discrimination are inter-related, moderate correlations $(<.40)$ confirm that they are distinct phenomena, with group discrimination being reported more frequently than personal discrimination. 
Gender (female dummy) and age (in years) were added as control variables, along with parental education (dummy which is one if one or both parents have maximally completed primary education). Table 1 displays descriptive information about all variables used in the analysis.

\section{TABLE 1 ABOUT HERE}

As Table 1 shows, Muslim participants in Stockholm are the least religious of the four comparison groups. Conversely, overall levels of religious identification and practices and political religion are highest among Muslim participants in Berlin. Keeping in mind previously described data constraints, however, mean differences across cities should be interpreted with caution due to the fact that mean levels are more susceptible to sampling bias than the associations between variables (Stoop et al., 2010, Van de Vijver and Leung, 1997).

\section{Method}

Multi-group confirmatory factor analysis was applied to establish measurement equivalence of latent dimensions of religiosity across the four cities for subsamples of self-categorized Muslims. ${ }^{4}$ Measurement equivalence is confirmed when the difference in $\chi^{2}$ between a fourgroup model with equality constraints on factor loadings and an unconstrained model is not significant (Schmitt and Kuljanin, 2008). Throughout our analysis, we report the values of $\chi^{2}$ in relation to the degrees of freedom (df), CFI and RMSEA as indicators of model fit, which is considered to be good if the $\chi^{2}$ /df ratio is approaching 1 , CFI is above .90 , and RMSEA is below .05 (Kline, 2005). Subsequently, we estimated a second-order factor model of religiosity with religious identification, dietary practices, worship and political religion as first-order factors. Using multi-group structural equation models, we replicated the hypothesized relationships of religiosity with religious socialization, structural integration, and perceived discrimination in the four cities, while controlling for gender, age and parental education. 
Integration and religiosity among the Turkish $2^{\text {nd }}$ generation

\section{Results}

Dimensions of religiosity

Confirmatory factor analyses largely support the equivalence of the four latent dimensions of religiosity across groups. Loadings of the four indicators on the latent variable religious identification could be set equal across the four cities, as evident from a non-significant $\chi^{2}$ difference between models with and without equality constraints $\left(\Delta \chi^{2}(9)=14.806, p>.05\right)$ and a good model fit of the factorially invariant model: $\chi^{2}(17,615)=27.272$, CFI $=0.979$, RMSEA $=0.031$. Concerning religious practices, full factorial invariance of the four indicators of worship and dietary practices is rejected: due to a lower loading of the halal item in Amsterdam, the $\chi^{2}$-difference test is significant at $p=0.042\left(\Delta \chi^{2}(6)=13.081\right)$. Because all loadings are significant and positive in the four cities and because the factorially invariant model fits the data well $\left(\chi^{2}(22,615)=39.780, \mathrm{CFI}=0.971, \mathrm{RMSEA}=0.036\right)$, loadings of religious practice items are set equal in comparative analyses across cities for the sake of parsimony. ${ }^{5}$ Regarding political religion, full factorial invariance was again rejected. The $\chi^{2}-$ difference test is significant at $p=0.038\left(\Delta \chi^{2}(9)=18.041\right)$ because the loading of the private religion item is non-significant in Stockholm. Again, we set loadings on political religion equal in comparative analysis since loading patterns are similar across cities and because the factorially invariant model fits the data well $\left(\chi^{2}(17,615)=30.104\right.$, CFI $=0.959$, RMSEA $=$ $0.046)$.

After establishing the measurement equivalence of religious identification, worship, dietary practices, and political religion across cities, a second-order factor model was estimated specifying one common factor, religiosity, which explains inter-factor correlations between the four dimensions of religiosity. This model fitted the data reasonably well: $\chi^{2}$ $(271,615)=512.010, \mathrm{CFI}=0.880, \mathrm{RMSEA}=0.038$. However, the loadings of the four religiosity dimensions on the second-order factor differ significantly between the four cities, as the model fit is significantly worse when loadings are set equal: $\Delta \chi^{2}(9)=39.667, p<.001$. In comparative analyses, the loadings on the second-order factor religiosity are estimated 
separately in each city while the loadings on the four dimensions of religiosity are constrained to be equal across cities. Figures $1 \mathrm{a}, \mathrm{b}, \mathrm{c}$ and $\mathrm{d}$ show the standardized factor loadings of religious identification, religious practices, and political religion in each city, revealing different patterns of religiosity among second-generation Turkish Muslims in the four cities.

\section{FIGURES 1A-1D ABOUT HERE}

In Berlin and Stockholm, very high loadings $(>.80)$ on all four dimensions of religiosity suggest rather undifferentiated patterns of religiosity. Turkish Muslims in these cities who are strongly committed to their Muslim identity also engage more frequently in religious practices and more strongly support political religion. In Amsterdam and Brussels, in contrast, patterns of religiosity are more selective; and political religion in particular is distinctive of only highly involved Muslims. To test our hypotheses, we predict religiosity from indicators of structural integration, religious socialization, and perceived discrimination while controlling for age, gender and parental education.

\section{Structural integration and secularization}

With regard to degrees of religiosity, including religious identification, worship, dietary practices, and political religion, the secularization hypothesis, which predicts religious decline with the structural integration of the second generation, is not supported in Amsterdam, Brussels and Stockholm; yet educational attainment is associated with lower religiosity in Berlin. Logistic regression of self-categorization as a Muslim yields parallel results (see Note 4), which shows that our findings apply not only to the degree of religiosity of the second generation, but also to religious self-identification. In support of differential associations, constraining the effects of educational and labour market attainment on religiosity to zero yields a significantly worse model fit only in Berlin, but not in the other three cities: $\Delta \chi^{2}(18)$ $=21.859, \mathrm{p}>.05$. Similarly, having a Turkish partner is associated with higher religiosity only in Berlin (although a non-Turkish partner has no additional effect on religiosity). In the 
Integration and religiosity among the Turkish $2^{\text {nd }}$ generation

other cities, religiosity is dissociated from the ethnicity of one's partner so that constraining the effects to zero does not significantly affect the model fit. This is found in all cities except Berlin: $\left.\Delta \chi^{2}(6)=7.762, p>.05\right)$. These findings are in line with hypothesized contextual differences as a function of the institutional accommodation of Islam. As expected, structural integration and religion are inversely related in the German capital, where Islam is least accommodated, yet they are decoupled in the other cities.

\section{Religious vitality and reactive religiosity}

In line with religious vitality, religious socialization has a strong impact on second-generation religiosity in all cities: Turkish Muslims who attended Koran lessons as a child or whose parents visited a mosque regularly are more religious. ${ }^{6}$ Finally, reactive religiosity is not supported, as associations with perceived discrimination disappear after taking into account religious socialization, structural integration, and controls. Accordingly, constraining the effects of personal and group-level discrimination to zero in all cities does not significantly affect model fit: $\Delta \chi^{2}(8)=9.323, p>.05$. Again, these effects are paralleled in logistic regressions predicting Muslim self-categorization. Table 2 shows within-group standardized parameter estimates for the final most restrictive structural equation models in the four cities. Only effects that are different from zero are included in this model. Squared multiple correlations indicate substantial explained variances in religiosity in all four cities, with most explained variance in Berlin and least in Stockholm. ${ }^{7}$

\section{TABLE 2 ABOUT HERE}

\section{Discussion}

Against the background of heated public debates, yet scant empirical evidence on the integration of Muslim minorities in Europe, this study analysed the relationship between structural integration and religiosity among the Turkish second generation. The secularization 
hypothesis, which expects religious decline with increasing levels of structural integration in mainstream societies, is tested together with a complementary hypothesis of religious vitality. The latter expects continued religiosity due to the religious socialization of the second generation within immigrant families and communities. In parallel, second-generation religion has been conceived as 'reactive' in response to perceived discrimination. Recently gathered cross-national data from the TIES-surveys among the Turkish second generation in major European cities allowed us to examine multiple dimensions of religiosity and to compare patterns of second-generation integration and religiosity between four European capital cities: Amsterdam, Berlin, Brussels, and Stockholm. Across cities, a majority of the Turkish second generation self-categorizes as Muslim and reports high overall levels of religious identification and practices, in line with earlier findings of sustained religiosity across generations of Turkish Muslims (Maliepaard et al., 2010, Diehl and Koenig, 2009, Phalet et al., 2008).

Comparative analyses revealed distinct components of religiosity, including religious identification, worship, dietary practices and political religion. Across cities, the same components constituted different patterns of religiosity, however, with less differentiated religious involvement among the second generation in Berlin and Stockholm and more selective patterns of religiosity in Amsterdam and Brussels. In the latter cities, political religion in particular was distinctive of only a subgroup of highly involved Muslims, while it was more closely associated with religious identity and practices in Berlin and Stockholm.

Turning to theoretical expectations of religious decline versus vitality in the second generation, we find support for the religious vitality hypothesis across the four cities whereas support for the secularization hypothesis is restricted to Berlin. Only here, educational attainment was inversely related to religiosity; in all other cities, second-generation religiosity was decoupled from structural integration. Differential associations of religiosity with integration point to the hypothesized moderating role of institutional accommodation. As expected, integration and religiosity were inversely related in the German context, where the state does not accommodate Islam as a minority religion. In the other contexts, where there is 
some degree of accommodation, religiosity was compatible with the structural integration of the second generation, in the sense of socio-economic inclusion and social mixing in mainstream society.

In line with our religious vitality hypothesis, we find that religious childhood socialization within Turkish immigrant families and communities strongly predicts continued religiosity in young adulthood. Second-generation Muslims whose parents visited a mosque more regularly or who attended Koran lessons as children were more religious later on in terms of their religious identification, practices and political religion in all four cities. This finding implies that the regulatory impact of different institutional arrangements is mostly restricted to that part of the social life of the second generation which is situated outside the co-ethnic community. Finally, and after taking into account religious socialization, we found no evidence of reactive religiosity.

Our findings should be interpreted with caution in light of data constraints. Firstly, the cross-sectional nature of the data does not permit us to empirically establish the direction of causality. Thus, we cannot be sure whether in Berlin higher education decreases religiosity, or high levels of religiosity hinder educational attainment, or whether the negative association of religion and integration works both ways. The issue of causal direction was not the main focus of our study, however, and our conclusions stand regardless of whether the negative association between religiosity and integration in Berlin works in either or both ways. The strength of the study is the comparative design, which allows us to replicate associations between integration and religion across four European capital cities which represent different models of church-state relations. Our finding of differential associations, in particular the lack of support for an inverse relationship of integration and religion in Amsterdam, Brussels and Stockholm, strongly suggests that there is nothing inherent in Islamic faith which would stand in the way of the integration of second-generation Muslims in European societies. The orthogonality of religion and structural integration is not an artefact due to a lack of variation in the structural integration of the Turkish second generation outside Berlin, since the marginal distributions of the four samples in Table 1 show that participants were similarly or 
more dispersed over different integration outcomes in Amsterdam, Brussels or Stockholm. Moreover, our analyses take into account competing explanations of religiosity from the differential selection of the first generation across the four cities; from childhood religious socialization; and from experiences of discrimination against Muslims. Taking into consideration these precautions, it seems plausible that different patterns of religiosity and integration between Berlin and the other capitals can be attributed at least in part to the cumulative impact of (the absence of) institutional recognition and accommodation in the receiving societies.

Secondly, our findings may be affected by low response rates to the TIES-surveys. In combination with different sampling frames, selective non-response implies that we cannot assume that the TIES-data are representative of the Turkish second generation, nor that participants are similarly selected in the four cities. Yet we found few differences in the selectivity of the first generation of Turkish immigrants across the four samples. Furthermore, we could establish measurement equivalence of latent dimensions of religiosity across cities. Finally, our comparative analyses are concerned with differential patterns and associations of religiosity rather than differences in absolute levels, which are most vulnerable to sampling and measurement bias (Van de Vijver and Leung, 1997, Stoop et al., 2010). For these reasons, the present analysis is a first step towards more comprehensive comparative analyses of religion among the European second generation, which should cross-validate our main finding of the conditional decoupling of religiosity and integration with other data sources.

Finally, our comparison is restricted to capital cities. To the extent that the differential institutionalization of Islam affects the relation between integration and religiosity, these effects of national institutions should show up in our comparative analysis. In support of our approach, previous research on public claims-making related to immigrant integration, revealed more variation between countries than between cities within the same country (Koopmans, 2004). Our findings should not be generalized to the national level, however, because, with only one city and one immigrant group per country, it is not possible to 
disentangle contextual variation at the level of cities or ethnic communities from countrylevel differences.

Keeping these limitations in mind, our results cast serious doubt on common assumptions of an inherent conflict between Islamic religiosity and the integration of the Muslim second generation in Europe. The fact that Berlin was the exception to the general rule of sustained religiosity combined with structural integration among the second generation highlights the distinctiveness of the German receiving context. Particularly in the religious domain, the lack of recognition and accommodation of the Muslim minority implies that Islam is treated as a second-class religion, leaving little room for a positive attachment to and active practice of this religion among most integrated Turkish Germans. The absence of a consistent trend towards lower religiosity with social mobility and social mixing in Amsterdam, Brussels and Stockholm implies that Islamic religiosity does not signify failed integration. Neither can it be interpreted in any straightforward way as a reaction of the second generation against perceived discrimination - despite widely shared perceptions that Muslims as a group are treated unfairly in European societies. Most importantly, in the presence of some degree of public recognition of Islam as a minority religion, structural integration is not significantly associated with religiosity. We conclude that religiosity is compatible with structural integration in more welcoming receiving contexts which accommodate religious diversity - albeit to varying degrees.

\section{Notes}

\footnotetext{
${ }^{1}$ Results not shown, available upon request. We compared rural or urban origin, year of migration, age at migration, migration motives and educational qualifications, as well as parents' employment status during participants' youth. Most parents originate from rural areas in Turkey and migrated to Western Europe in the late 1960s and early 1970s, with mean age at migration between 18 and 23 years. Most fathers migrated for economic reasons, while mothers generally migrated for family reunification or formation. Most parents had little or no formal education, with somewhat higher levels in Brussels and Stockholm. Most fathers were working in unskilled or skilled manual jobs when participants were
} 
fifteen years old, while mothers were mostly homemakers; in Brussels and Stockholm, however, mothers' levels of labour market participation were higher.

${ }^{2}$ Because mosque visiting is gendered with higher attendance among men (cf. Diehl \& Koenig, 2009), a direct effect of gender on mosque attendance is included in all models.

${ }^{3}$ The levels of education distinguished correspond to the International Standard Classification of Education (ISCED; UNESCO 1997), with low education representing ISCED-2 and below, vocational referring to ISCED-3B, upper secondary to ISCED-3A and tertiary to ISCED-5 and higher.

${ }^{4}$ Self-categorized Muslims are participants who indicated that they currently had a religion and that this religion was Islam. Religious affiliation was used as a routing question in computer-assisted personal interviews such that participants who indicated that they had no religion did not answer questions on religious identification and practice. The wording of the routing question deviated in Berlin where participants were asked "Are you currently religious?" This wording may have resulted in a greater selectivity of participants who completed the religiosity measures in Berlin. We analysed selfcategorization as Muslims using all independent variables as predictors in logistic regression. These results (not shown, available upon request) replicate similar context-dependent associations of religious membership with structural integration, religious socialization and perceived discrimination.

${ }^{5}$ Moreover, model fit statistics suggest that the distinction between the two religious practice scales fits better to the data, compared to a model where all four indicators load on one common practice scale. Akaike's Information Criterion (AIC) is used to compare these competing models, with smaller values indicating better fit (Kline, 2005, Hu and Bentler, 1999). AIC is 186.316 for a model with only one religious practice scale, while a model with two correlated practice scales has an AIC of 155.780, ceteris paribus.

${ }^{6}$ The effects of Koran lessons and parental religiosity are not significant in Stockholm, yet constraining them to zero results in significantly worse model fit $\left(\Delta \chi^{2}(2)=8.144, \mathrm{p}=0.017\right)$.

${ }^{7}$ Table 2 also shows the loadings of the religiosity dimensions on the second-order factor after including all explanatory and control variables. Despite some changes in magnitude, the loadings still differ significantly between the four cities; constraining them to be equal results in significantly worse model fit: $\Delta \chi^{2}(9)=38.733, \mathrm{p}<.001$. 
Integration and religiosity among the Turkish $2^{\text {nd }}$ generation

References

ALWALL, JONAS 2000 'Religious liberty in Sweden: an overview', Journal of Church and State, vol. 42, no. 1 , pp. 147-171

BADER, VEIT 2007 'The Governance of Islam in Europe: The Perils of Modelling', Journal of Ethnic and Migration Studies, vol. 33, no. 6, pp. 871-886

BERGER, PETER L. 1967 The sacred canopy. Elements of a sociological theory of religion, Garden City: Doubleday

BOUSETTA, HASSAN 2000 'Institutional theories of immigrant ethnic mobilisation: relevance and limitations', Journal of Ethnic and Migration Studies, vol. 26, no. 2, pp. 229-245

CASANOVA, JOSÉ 2003 'Beyond European and American exceptionalisms: towards a global perspective', in Grace Davie, Paul Heelas and Linda Woodhead (eds), Predicting religion. Christian, secular and alternative futures, Aldershot: Ashgate, pp. $17-29$

CEIFO 2008 TIES07-08 - Sweden,

CESO-CSCP 2008 TIES07-08 - Belgium,

CONNOR, PHILLIP 2010 'Contexts of immigrant receptivity and immigrant religious outcomes: the case of Muslims in Western Europe', Ethnic and Racial Studies, vol. 33, no. 3, pp. 376-403

CORMAN, DIANA 2008 'Sveriges invandring och utvandring', in Mehrdad Darvishpour and Charles Westin (eds), Migration och etnicitet. Perspektiv på ett mångkulturellt Sverige, Lund: Studentlitteratur, pp. 175-192

CRUL, MAURICE \& SCHNEIDER, JENS 2010 'Comparative integration context theory: participation and belonging in new diverse European cities', Ethnic and Racial Studies, vol. 33, no. 7, pp. 1249-1268

DIEHL, CLAUDIA \& KOENIG, MATTHIAS 2009 'Religiosität türkischer Migranten im Generationenverlauf: ein Befund und einige Erklärungsversuche', Zeitschrift für Soziologie, vol. 38, no. 4, pp. 300-319 
DOBBELAERE, KAREL 1981 Secularization: A Multi-Dimensional Concept: Current Sociology Series Volume 29 Nr. 2.

DOOMERNIK, JEROEN 1995 'The institutionalization of Turkish Islam in Germany and the Netherlands: a comparison', Ethnic and Racial Studies, vol. 18, no. 1, pp. 46-63

ESSER, HARTMUT 2001 'Integration und ethnische Schichtung'. Mannheim: Arbeitspapiere - Mannheimer Zentrum für Europäische Sozialforschung

FETZER, JOEL S. \& SOPER, J. CHRISTOPHER 2005 Muslims and the state in Britain, France, and Germany, Cambridge: Cambridge University Press

FOBLETS, MARIE-CLAIRE \& OVERBEEKE, ADRIAAN 2002 'State intervention in the institutionalisation of Islam in Belgium', in Wasif A.R. Shadid and Sjoerd Van Koningsveld (eds), Religious freedom and the neutrality of the state: The position of Islam in the European Union, Leuven: Peeters, pp. 113-128

FONER, NANCY \& ALBA, RICHARD 2008 'Immigrant religion in the U.S. and Western Europe: Bridge or barrier to inclusion?', International Migration Review, vol. 42, no. 2, pp. 360-392

GORDON, MILTON M. 1978 [1964] Assimilation in American Life: The role of race, religion and national origins, New York: Oxford University Press

GORSKI, PHILIP S. \& ALTINORDU, ATES 2008 'After secularisation?', Annual Review of Sociology, vol. 34, pp. 55-85

GROENEWOLD, GEORGE 2008 'Appendix: Sample design, TIES survey implementation and evaluation', in Maurice Crul and Liesbeth Heering (eds), The Position of the Turkish and Moroccan Second Generation in Amsterdam and Rotterdam. The TIES study in the Netherlands, Amsterdam: Amsterdam University Press, pp. 169-179

GÜNGÖR, DERYA, FLEISCHMANN, FENELLA \& PHALET, KAREN forthcoming 'Religious Identification, Beliefs, and Practices among Turkish-Belgian and Moroccan-Belgian Muslims: Intergenerational Continuity and Acculturative Change', Journal of Cross-Cultural Psychology, 
Integration and religiosity among the Turkish $2^{\text {nd }}$ generation

HARWOOD, JAKE, GILES, HOWARD \& BOURHIS, RICHARD Y. 1994 'The genesis of vitality theory: historical patterns and dissoursal dimensions', International Journal of the Sociology of Language, vol. 108, pp. 167-206

HU, LI-TZE \& BENTLER, PETER M. 1999 'Cutoff criteria for fit indexes in covariance structure analysis: conventional criteria versus new alternatives', Structural equation modeling, vol. 6 , no. 1 , pp. 1-55

IMIS 2008 TIES08-Germany,

KANMAZ, MERYEM 2002 'The recognition and institutionalisation of Islam in Belgium', Muslim world, vol. 92, no. 1/2, pp. 99-114

KELLEY, JONATHAN \& DE GRAAF, NAN DIRK 1997 'National context, parental socialization, and religious belief: Results from 15 nations', American Sociological Review, vol. 62, no. 4, pp. 639-659

KLINE, REX 2005 Principles and practice of structural equation modelling, 2nd ed, New York: Guilford Press

KOENIG, MATTHIAS 2007 'Europeanising the governance of religious diversity: An institutionalist account of Muslim struggles for public recognition', Journal of Ethnic and Migration Studies, vol. 33, no. 6, pp. 911-932

KOOPMANS, RUUD 2004 'Migrant mobilisation and political opportunities: variation among German cities and a comparison with the United Kingdom and the Netherlands', Journal of Ethnic and Migration Studies, vol. 30, no. 3, pp. 449-470

LESTHAEGHE, RON 2000 'Communities and generations. Turkish and Moroccan populations in Belgium'. Brussels: VUB University Press

LESTHAEGHE, RON \& NEELS, KAREL 2000 'Islamic communities in Belgium: religious orientations and secularization', in Ron Lesthaeghe (ed) Communities and Generations. Turkish and Moroccan populations in Belgium., Brussels: VUB University Press, pp. 129-163

MALIEPAARD, MIEKE, LUBBERS, MARCEL \& GIJSBERTS, MÉROVE 2010 'Generational differences in ethnic and religious attachment and their interrelation. A 
study among Muslim minorities in the Netherlands', Ethnic and Racial Studies, vol. 33, no. 3, pp. $451-472$

MANÇO, URAL 2000 Voix et voies musulmanes de Belgique, Brussels: FUSL

MÜNZ, RAINER, SEIFERT, WOLFGANG \& ULRICH, RALF 1997 Zuwanderung nach Deutschland. Strukturen, Wirkungen, Perspektiven, Frankfurt: Campus

NIDI-IMES 2007 TIES06-07 Netherlands,

NORRIS, PIPPA \& INGLEHART, RONALD 2004 Sacred and secular. Religion and politics worldwide, Cambridge: Cambridge University Press

PHALET, KAREN, DEBOOSERE, PATRICK \& BASTIAENSSEN, VICKY 2007 'Old and new inequalities in educational attainment. Ethnic minorities in the Belgian Census 1991-2001', Ethnicities, vol. 7, no. 3, pp. 390-415

PHALET, KAREN, FLEISCHMANN, FENELLA \& STOIJCIC, SNEZANA in preparation 'Ways of being Muslim: religious identities of second-generation Turkish Muslims in seven European cities',

PHALET, KAREN, GIJSBERTS, MÉROVE \& HAGENDOORN, LOUK 2008 'Migration and religion: Testing the limits of secularisation among Turkish and Moroccan Muslims in the Netherlands 1998-2005', Kölner Zeitschrift für Soziologie und Sozialpsychologie, vol. SH 48, pp. 412-436

PORTES, ALEJANDRO \& RUMBAUT, RUBEN G. 2001 Legacies. The story of the immigrant second generation, Berkeley: University of California Press

RATH, JAN, et al. 1996 Nederland en zijn islam. Een ontzuilende samenleving reageert op het ontstaan van een geloofsgemeenschap Amsterdam: Het Spinhuis

RENSTRAND, NILS \& LUNDSTRÖM, SIXTEN 2008 'Personliga ervarenheter av integration i Stockholms län. En undersökning på uppdrag av Centrum för forskning om internationell migration och etniska relationer (CEIFO) vid Stockholms universitet. Teknisk rapport'. Stockholm: SCB/DIH

SANDER, ÅKE 1990 'Islam and Muslims in Sweden', Migration, vol. 8, pp. 87-134 
Integration and religiosity among the Turkish $2^{\text {nd }}$ generation

SCHMITT, NEIL \& KULJANIN, GORAN 2008 'Measurement invariance: review of practice and implications', Human Resource Management Review, vol. 18, no. 4, pp. 210-222

SMITS, FRANSJE, RUITER, STIJN \& VAN TUBERGEN, FRANK 2010 'Religious practices among Islamic immigrants: Moroccan and Turkish men in Belgium', Journal for the Scientific Study of Religion, vol. 49, no. 2, pp. 247-263

SNIDERMAN, PAUL M. \& HAGENDOORN, LOUK 2007 When ways of life collide. Multiculturalism and its discontents in the Netherlands, Princeton: Princeton University Press

STATHAM, PAUL, et al. 2005 'Resilient or adaptable Islam? Multiculturalism, religion and migrants' claims-making for group demands in Britain, the Netherlands and France', Ethnicities, vol. 5, no. 4, pp. 427-549

STATISTISCHES BUNDESAMT 2010 'Bevölkerung mit Migrationshintergrund Ergebnisse des Mikrozensus 2009', Fachserie 1 Reihe 2.2. Wiesbaden: Statistisches Bundesamt

STATLINE 2010 'Bevolking; generatie, geslacht, leeftijd en herkomstgroepering, 1 januari'. Centraal Bureau voor de Statistiek

STOOP, INEKE, et al. 2010 Improving survey response. Lessons learned from the European Social Survey, Chichester: Wiley

SWYNGEDOUW, MARC, et al. 2008 'Technical Report TIES 2007-2008 Belgium Extended. Trajectories and Experiences of Turkish, Moroccan and Native Belgians in Antwerp and Brussels'. Leuven: CeSo/CSCP

UNESCO 1997 International Standard Classification of Education (ISCED), Paris: UNESCO VAN DE VIJVER, FONS J.R. \& LEUNG, KWOK 1997 Methods and data analysis for cross-cultural research, London: Sage

VAN TUBERGEN, FRANK 2007 'Religious affiliation and participation among immigrants in a secular society: A study of immigrants in the Netherlands', Journal of Ethnic and Migration Studies, vol. 33, no. 5, pp. 747-765 
VERMEULEN, HANS \& PENNINX, RINUS 2000 Immigrant integration: the Dutch case, Amsterdam: Spinhuis

WESTIN, CHARLES 2003 'Young people of migrant origin in Sweden', International Migration Review, vol. 37, no. 4, pp. 987-1010 
Table 1. Descriptive statistics

\begin{tabular}{|c|c|c|c|c|c|}
\hline \multirow{3}{*}{$\mathrm{N}$} & \multirow[b]{3}{*}{ Range } & \multirow{2}{*}{$\begin{array}{c}\text { Amsterdam } \\
237\end{array}$} & \multirow{2}{*}{$\begin{array}{c}\text { Berlin } \\
253\end{array}$} & \multirow{2}{*}{$\begin{array}{c}\text { Brussels } \\
250\end{array}$} & \multirow{2}{*}{$\begin{array}{c}\text { Stockholm } \\
185\end{array}$} \\
\hline & & & & & \\
\hline & & Mean (S.D.) & Mean (S.D.) & Mean (S.D.) & Mean (S.D.) \\
\hline \multicolumn{6}{|l|}{ Religion } \\
\hline Self-categorized Muslim & $0 / 1$ & 0.70 & 0.62 & 0.71 & 0.63 \\
\hline \multicolumn{6}{|l|}{ Religious socialization } \\
\hline Attended Koran school & $0 / 1$ & 0.58 & 0.45 & 0.30 & 0.30 \\
\hline Frequency of parental mosque visit & $1 / 5$ & $2.38(2.08)$ & $3.25(1.46)$ & $2.29(1.87)$ & $1.69(1.92)$ \\
\hline \multicolumn{6}{|l|}{ Religious identification } \\
\hline Being a Muslim is an important part of myself & $1 / 5$ & $4.31(0.86)$ & $4.28(0.67)$ & $4.20(0.92)$ & $4.55(0.82)$ \\
\hline The fact that I am a Muslim is something I often think about & $1 / 5$ & $3.66(1.16)$ & $3.73(1.04)$ & $4.05(1.01)$ & $3.77(1.47)$ \\
\hline I see myself as a true Muslim & $1 / 5$ & $3.78(0.97)$ & $4.15(0.75)$ & $3.87(1.00)$ & $3.77(1.31)$ \\
\hline When somebody says something bad about Muslims, I feel personally hurt & $1 / 5$ & $3.80(1.11)$ & $4.20(0.85)$ & $4.00(1.08)$ & $3.17(1.57)$ \\
\hline \multicolumn{6}{|l|}{ Dietary practices } \\
\hline Ramadan & $1 / 5$ & $4.07(1.47)$ & $3.90(1.25)$ & $3.84(1.48)$ & $2.75(1.75)$ \\
\hline Halal food & $1 / 5$ & $4.33(0.97)$ & $3.79(1.19)$ & $4.49(1.03)$ & $3.15(1.50)$ \\
\hline \multicolumn{6}{|l|}{ Worship } \\
\hline Daily Prayer & $1 / 5$ & $2.48(1.51)$ & $3.52(1.09)$ & $2.37(1.30)$ & $2.26(1.23)$ \\
\hline Mosque visit & $1 / 5$ & $2.60(1.38)$ & $3.71(0.95)$ & $2.59(1.14)$ & $2.69(1.39)$ \\
\hline \multicolumn{6}{|l|}{ Political Religion } \\
\hline Religion should be a private matter between the believer and God* & $1 / 5$ & $4.25(0.83)$ & $4.20(0.86)$ & $4.47(0.86)$ & $4.85(0.54)$ \\
\hline Islam should be represented in politics and society & $1 / 5$ & $2.68(1.10)$ & $2.95(1.23)$ & $2.64(1.21)$ & $1.84(1.22)$ \\
\hline Islam should be the only and ultimate authority in political matters & $1 / 5$ & $2.25(1.08)$ & $2.58(1.33)$ & $2.15(1.03)$ & $1.22(0.70)$ \\
\hline Muslim women should cover their head when outside the home & $1 / 5$ & $2.72(1.22)$ & $2.92(1.44)$ & $2.52(1.16)$ & $1.89(1.18)$ \\
\hline \multicolumn{6}{|l|}{ Structural integration } \\
\hline Lower secondary education or less & $0 / 1$ & 0.27 & 0.32 & 0.25 & 0.07 \\
\hline Vocational education & $0 / 1$ & 0.38 & 0.53 & 0.26 & 0.24 \\
\hline Upper secondary education & $0 / 1$ & 0.04 & $0 . .08$ & 0.26 & 0.28 \\
\hline Tertiary education & $0 / 1$ & 0.29 & 0.07 & 0.23 & 0.28 \\
\hline Working & $0 / 1$ & 0.57 & 0.58 & 0.50 & 0.72 \\
\hline Unemployed & $0 / 1$ & 0.10 & 0.21 & 0.22 & 0.08 \\
\hline Full-time student & $0 / 1$ & 0.18 & 0.08 & 0.22 & 0.15 \\
\hline Otherwise inactive & $0 / 1$ & 0.13 & 0.13 & 0.05 & 0.05 \\
\hline No partner & $0 / 1$ & 0.55 & 0.55 & 0.60 & 0.50 \\
\hline Turkish partner & $0 / 1$ & 0.41 & 0.34 & 0.31 & 0.40 \\
\hline Non-Turkish partner & $0 / 1$ & 0.04 & 0.11 & 0.09 & 0.10 \\
\hline \multicolumn{6}{|l|}{ Perceived discrimination } \\
\hline Perceived personal discrimination & $1 / 5$ & $1.88(1.10)$ & $2.11(0.89)$ & $1.98(0.98)$ & $1.89(1.06)$ \\
\hline Perceived group discrimination: Muslims & $1 / 5$ & $3.92(1.27)$ & $3.33(1.18)$ & $3.35(1.10)$ & $3.71(1.05)$ \\
\hline \multicolumn{6}{|l|}{ Control variables } \\
\hline Female & $0 / 1$ & 0.54 & 0.44 & 0.36 & 0.57 \\
\hline Age & $18 / 36$ & $24.5(4.3)$ & $26.2(5.3)$ & $25.7(5.2)$ & $25.6(4.8)$ \\
\hline Parental education: one or both primary or less & $0 / 1$ & 0.71 & 0.80 & 0.44 & 0.65 \\
\hline
\end{tabular}

* This indicator loads negatively on the political religion scale. No standard deviation shown for dichotomous variables. 
Table 2. Multi-group structural equation models of religiosity (standardized coefficients)

\begin{tabular}{|c|c|c|c|c|}
\hline & Amsterdam & Berlin & Brussels & Stockholm \\
\hline $\mathrm{N}$ & 166 & 156 & 177 & 116 \\
\hline \multicolumn{5}{|l|}{ Predictors } \\
\hline Age & $-0.184 *$ & -0.108 & -0.023 & -0.196 \\
\hline Female $(0 / 1)$ & -0.017 & 0.103 & -0.041 & -0.206 \\
\hline Parental education & 0.013 & -0.019 & -0.053 & 0.097 \\
\hline Koran school (0/1) & $0.270 *$ & $0.441 * * *$ & $0.174 *$ & 0.159 \\
\hline Parental mosque visit & $0.373 * *$ & $0.434 * * *$ & $0.364 * * *$ & 0.170 \\
\hline \multicolumn{5}{|l|}{ Education } \\
\hline Vocational $(0 / 1)$ & 0 & $-0.233 * * *$ & 0 & 0 \\
\hline Upper secondary $(0 / 1)$ & 0 & $-0.120 *$ & 0 & 0 \\
\hline Tertiary $(0 / 1)$ & 0 & $-0.151 *$ & 0 & 0 \\
\hline Otherwise inactive (0/1) & 0 & 0 & 0 & 0 \\
\hline Full-time student $(0 / 1)$ & 0 & 0 & 0 & 0 \\
\hline Unemployed (0/1) & 0 & 0 & 0 & 0 \\
\hline Turkish partner $(0 / 1)$ & 0 & $0.182 * *$ & 0 & 0 \\
\hline Non-Turkish partner $(0 / 1)$ & 0 & 0.009 & 0 & 0 \\
\hline Personal discrimination & 0 & 0 & 0 & 0 \\
\hline Group discrimination & 0 & 0 & 0 & 0 \\
\hline \multicolumn{5}{|l|}{ Loadings } \\
\hline Religious identification & $0.676^{\mathrm{a}}$ & $0.876^{\mathrm{a}}$ & $0.932^{\mathrm{a}}$ & $0.680^{\mathrm{a}}$ \\
\hline Dietary practices & $0.790 * * *$ & $0.991 * * *$ & $0.677 * * *$ & $0.723 * * *$ \\
\hline Worship & $0.802 * * *$ & $0.734 * * *$ & $0.680 * * *$ & $0.743 * * *$ \\
\hline Political religion & $0.446 * * *$ & $0.696 * * *$ & $0.579 * * *$ & $0.541 * * *$ \\
\hline $\begin{array}{l}\text { Squared multiple } \\
\text { correlation }\end{array}$ & 0.398 & 0.635 & 0.207 & 0.199 \\
\hline
\end{tabular}

*** $\mathrm{p}<.001, * * \mathrm{p}<.01, * \mathrm{p}<.05$.

${ }^{a}$ The unstandardized loading of religious identification on the second-order factor religiosity was fixed to one. 
Integration and religiosity among the Turkish $2^{\text {nd }}$ generation

Figure 1(a). Second-order factor model of religiosity (standardized loadings): Amsterdam

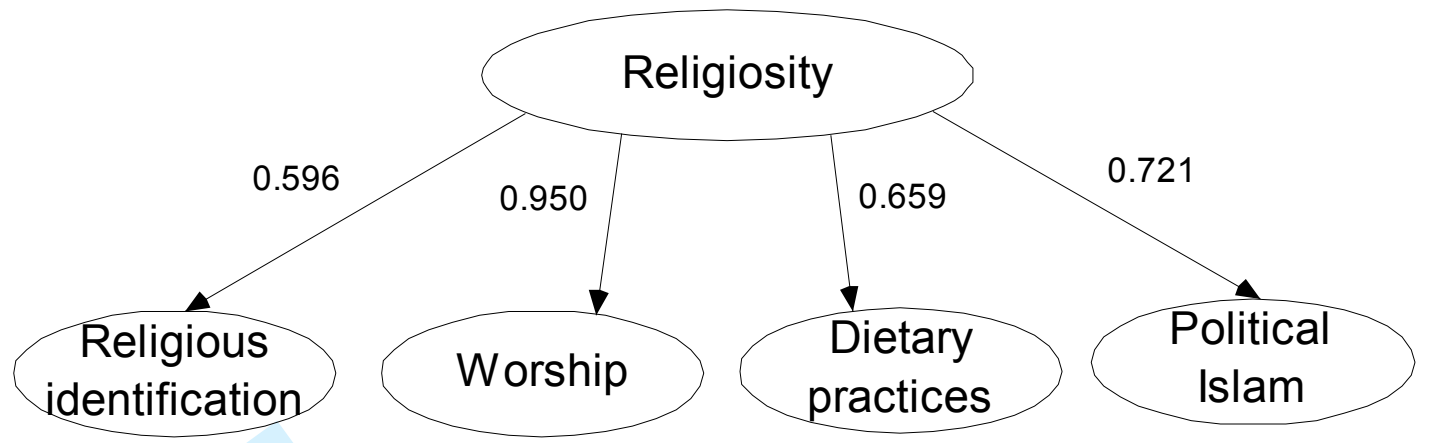


Figure 1(b). Second-order factor model of religiosity (standardized loadings): Berlin

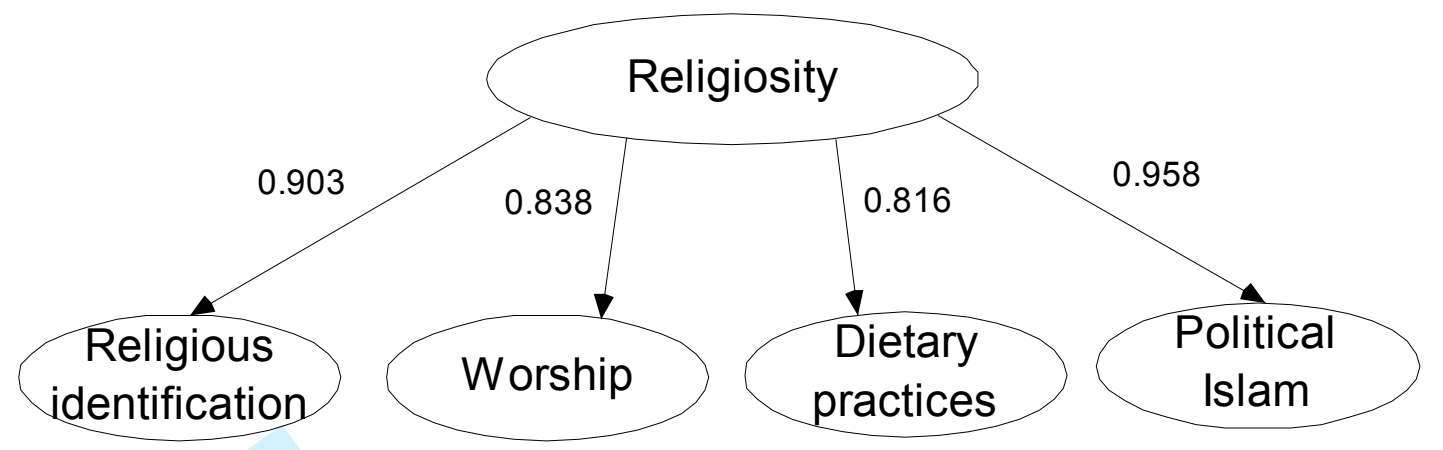


Integration and religiosity among the Turkish $2^{\text {nd }}$ generation

Figure 1(c). Second-order factor model of religiosity (standardized loadings): Brussels

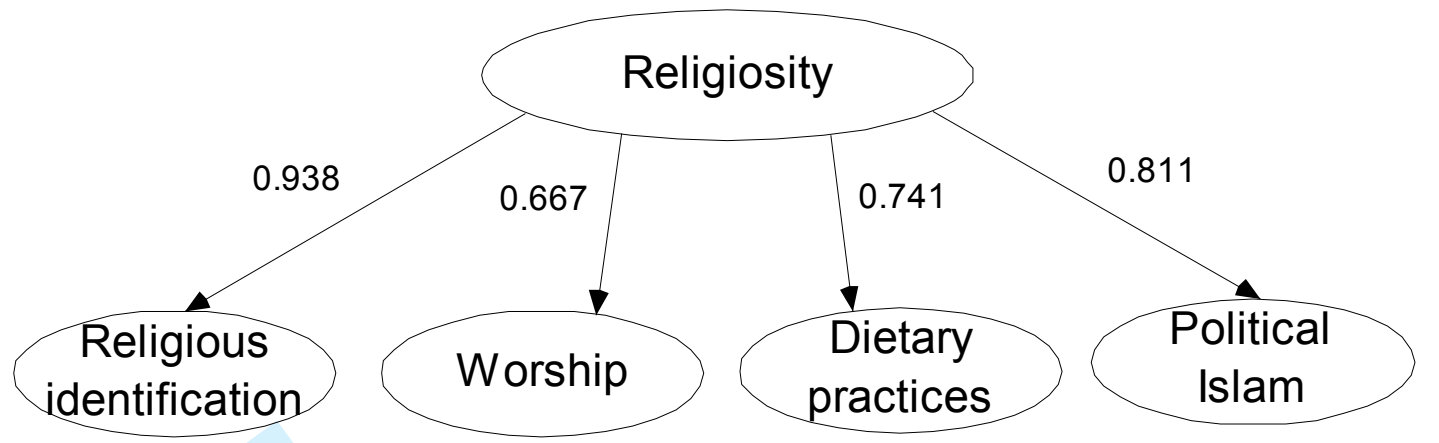


Figure 1(d). Second-order factor model of religiosity (standardized loadings): Stockholm

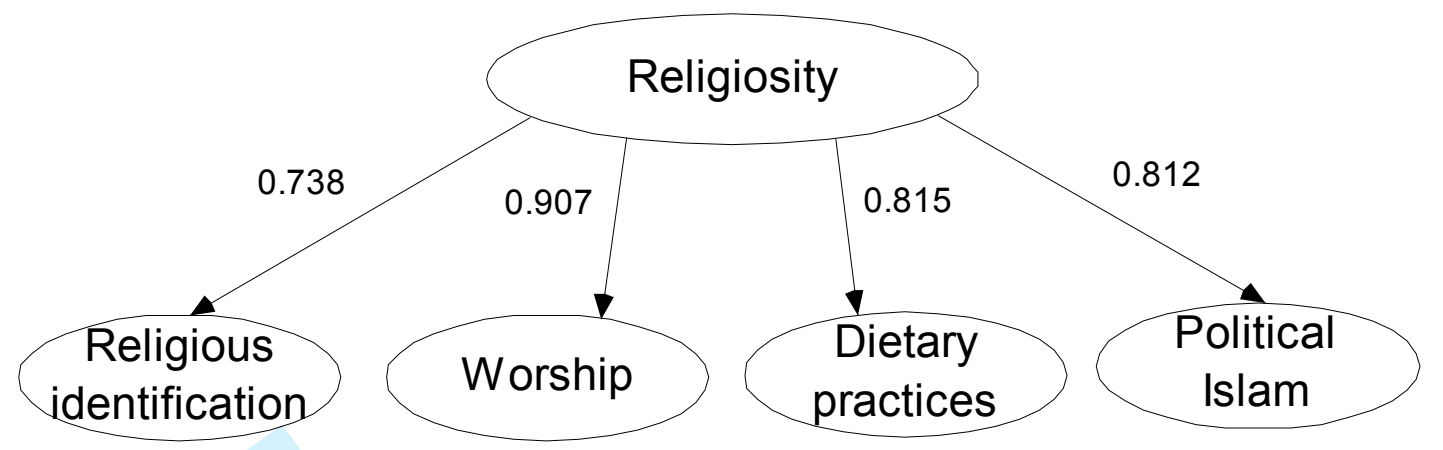


FENELLA FLEISCHMANN is Senior Researcher in the Department Migration, Integration, Transnationalization at the Social Science Research Centre Berlin (WZB). ADDRESS: Social Science Research Centre, Reichpietschufer 50, 10785 Berlin, Germany. Email: fleischmann@wzb.eu

KAREN PHALET is Full Professor in the Centre for Social and Cultural Psychology at the University of Leuven.

ADDRESS: Centre for Social and Cultural Psychology, Tiensestraat 102, PO Box 3727, B-3000 Leuven, Belgium. Email: Karen.phalet@psy.kuleuven.be 